\title{
CORRESPONDENCE
}

\section{Marine stewardship: catalysing change}

Criticisms that the Marine Stewardship Council (MSC) programme is not delivering on its promise (Nature 467, 28-29 and $531 ; 2010)$ are misplaced. After ten years of operation, the MSC certification programme is helping to generate real benefits for the marine environment, including increased stock health, reduced by-catch, established no-take zones, reduced impact on marine habitats and improved scientific understanding through research.

For example, as a condition of certification, the South African hake fishery implemented measures that have reduced by-catch of seabirds from 18,000 per year to less than 200 . The Dutch Ekofish North Sea plaice fishery has established a voluntary agreement with the World Wide Fund for Nature (WWF) and the North Sea Foundation to minimize impact by closing selected areas to fishing. In British Columbia, certification of the Nass River sockeye-salmon fishery is contingent on implementation of an effective recovery plan for chum salmon stocks. The Norwegian biotech firm Aker BioMarine has undertaken new research and surveys to ensure even better future management of the Antarctic krill resource (in a fishery that, in total, takes less than $1 \%$ of the available biomass). There is a proven ecological case for credible third-party certification.

The MSC has committed considerable resources to its developing-world programme, in particular by developing the Risk-Based Framework methodology for assessing data-poor fisheries. This is being used in assessments of pole and line and hand-line tuna fisheries in the Maldives, and in the Sian Ka'an and Banco Chinchorro lobster fishery in Mexico. An increasing number of fisheries in Africa, Asia and small island states in the Pacific Ocean are all engaged at various stages of the independent assessment process and we expect this trend to continue. We have expert developing-world representatives on our Technical Advisory Board and Stakeholder Council.

We - along with many scientists, experts, partners and stakeholders worldwide - have confidence in the rigour of our standard and methodology. The MSC is helping to transform the way the oceans are fished. More than $90 \%$ of the world's fisheries are not MSC certified: engaging those fisheries to achieve and establish their sustainability is the challenge that faces us all. Rupert Howes Marine Stewardship Council, UK, rupert.howes@msc.org

\section{Pakistan: why the reforms need work}

I agree that investing in Pakistan's higher education will have a broad impact on development (Nature $467,367 ; 2010)$. But at policy level, some things are different from the situation described by you and the Higher Education Commission overseeing this reform process.

The commission must prioritize according to the country's needs.

For example, we badly need social scientists (economists, sociologists and anthropologists) to help to set goals of human development and social welfare.

The commission is unrealistic in suggesting that producing more $\mathrm{PhDs}$ locally and from advanced industrial countries will boost the knowledge economy. Establishing new universities in remote districts is unlikely to attract more foreign graduates and invitee professors, who will continue to favour the metropolitan universities because of their better infrastructure.
The reform process is being partly funded by foreign partners, but it is not clear how much longer this can be sustained. And Pakistan's low tax-to-GDP ratio, coupled with burgeoning corruption (tax theft), won't help to increase local funding for higher education.

Faisal Abbas University of Bonn, Germany,fabbas@uni-bonn.de

\section{Pakistan: the brain drain dilemma}

In your assessment of the bleak state of academic and scientific research in Pakistan (Nature $467,378-379 ; 2010$ ), you do not mention the country's 'brain drain' problem.

A nation's research achievements depend mainly on the experience and expertise of its available researchers. But the current trend for Pakistan's new $\mathrm{PhDs}$ is to pursue their postdoctoral training abroad and eventually to take up employment there. Few of these well-trained researchers return home, discouraged by factors such as corruption, political instability, lack of governmental initiative and inadequate healthcare and social-security benefits.

In the absence of resident high-calibre scientists, even adequate funding will make little or no difference to the existing system.

Yajnavalka Banerjee Sultan Qaboos University, Oman, yaj@squ.edu.om

\section{Safaris can help conservation}

Conservation doesn't always alleviate poverty, and commercial ecotourism doesn't always protect biodiversity (Nature 467, 264-265; 2010) - but both succeed often enough to be worth doing.

A few tourism enterprises have made globally significant contributions to conservation. The safari company \&Beyond, for example, protects $2 \%$ of the world's black rhinos and $1 \%$ of white rhinos on two of its 50 properties, as well as $4 \%$ of the Aders' duiker (Cephalophus adersi) antelope population and $10 \%$ of suni antelopes (Neotragus moschatus) on two others.

In addition, Wilderness

Safaris protects $8 \%$ of the world's remaining population of an endangered bird, the Seychelles white-eye (Zosterops modestus) on one of the company's 60 properties. For further details, see go.nature.com/g8Z4Pj.

Ralf Buckley Griffith University, Queensland, Australia, r.buckley@griffith.edu.au

\section{Fate of 'retired' research chimps}

Your News story on the return of a colony of elderly research chimpanzees to the lab (Nature 467, 507-508; 2010) inadvertently misrepresents my position on an important and sensitive issue.

Like many others on the sidelines of this acrimonious debate, I see a middle path that seems reasonable. Given that chimpanzees in captivity cannot be returned to the wild, these individuals should be studied with care. This means following similar conditions and principles to those used for research on human subjects who are incapable of giving informed consent. Such studies would be of great benefit to chimpanzees and to humans.

I do not understand the call for a complete ban on all research on captive chimpanzees. Would anyone support a complete ban on all research on humans? Such a ban would be bad for both species. Ajit Varki University of California, San Diego, USA, alvarki@ucsd.edu 